\title{
STATUS GIZI BERHUBUNGAN DENGAN KEJADIAN ANEMIA PADA REMAJA PUTRI DI SMAN 1 PAGELARAN PRINGSEWU
}

\author{
THE NUTRITIONAL STATUS OF RELATIONS WITH ANEMIA ON SCENE \\ ADOLESCENT GIRLS AT SMAN 1 PAGELARAN PRINGSEWU
}

\author{
Daholal Jannah ${ }^{1}$, Sumi Anggraeni ${ }^{2}$ \\ ${ }^{1,2}$ Fakultas Kesehatan Universitas Muhammadiyah Pringsewu \\ Email: Jannah@gmail.com
}

\begin{abstract}
Abstrak : The Nutritional Status Of Relations With Anemia On Scene Adolescent Girls At SMAN 1 Pagelaran Pringsewu. Malnutrition and an impairment of health can be damaging to the quality of human resources. In Indonesia there are still four main nutritional problems, namely lack of protein energy (KEP), disorders due to lack of iodine (IDD), deficiency of vitamin A (VAD) and anemia due to iron deficiency (AGB) the insidence of anemia in adolescent reaches a presentation of 33,7 \%. The impact of anemia on adolencent girls results in dereased achievemnet, so that at times they will become prospective mothers with high risk condiitons The purpose of this study which is to know the nutritional status of relations with the genesis anemia in adolescent girls at SMAN 1 Pagelaran Pringsewu.The kind of research design was used in the descriptive analytic research, as well as adopting both cross sectional and tekhnik used was a total of sampling with the total sample 96 respondents by means of checklist fill a sheet . Based on statistical tests using test chi-square produce value pvalue $<0.05$ namely $\mathrm{p}$ value $=0,000$, there is a coralation between the nutritional status with the anemia in adolescent girls di SMAN 1 Pagelaran. Researchers suggested in the school to increase socialization means choosing healthy food.
\end{abstract}

Key Words : Anemia Accidentally, The nutritional status of teenagers.

\section{Abtrak : Status Gizi Berhubungan Dengan Kejadian Anemia Pada Remaja Putri Di SMA}

N 1 Pagelaran Pringsewu. Kekurangan gizi dan gangguan kesehatan dapat merusak kualitas sumber daya manusia. Di Indonesia masih terdapat empat masalah gizi utamaya itu kurang energi protein (KEP), gangguan akibat kurang iodium (GAKI), kurang vitamin A (KVA) dan anemia akibat kekurangan gizi besi (AGB), angka kejadian anemia pada remaja mencapai presentasi 33,7\%. Dampak anemia pada remaja putri mengakibatkan kebugaran atau kesegaran tubuh berkurang semangat belajar atau prestasi menurun, sehingga pada saat akan menjadi calon ibu dengan keadaan beresiko tinggi. Tujuan dari penelitian ini yaitu untuk mengetahui hubungan status gizi dengan kejadian anemia pada remaja putri di SMAN 1 Pagelaran Pringsewu t. Jenis penelitian ini menggunakan desain penelitian deskriptif analitik, serta menggunakan pendekatan cross sectional dan tekhnik yang digunakan adalah total sampling dengan jumlah sampel 96 responden dengan cara mengisi lembar checklist. Berdasarkan uji statistik menggunakan uji chi-square menghasilkan nilai pvalue $<0,05$ yaitu $\mathrm{p}$ value $=0,000$, yang berarti ada hubungan antara status gizi dengan kejadian anemia pada remaja putri di SMAN 1 Pagelaran Pringsewu. Peneliti menyarankan pada pihak sekolah untuk lebih meningkatkan sosialisasi cara memilih makanan yang sehat.

Kata kunci : Kejadian Anemia, Status Gizi Remaja 


\section{PENDAHULUAN}

Kekurangan gizi dan gangguan kesehatan dapat merusak kualitas sumber daya manusia (SDM). Sampai saat ini di Indonesia masih terdapat empat masalah gizi utamaya itu kurang energi protein (KEP), gangguan akibat kurang iodium (GAKI), kurang vitamin A (KVA) dan anemia akibat kekurangan gizi besi (AGB). Berbagai krisis dan bencana yang dialami Indonesia pada dasawarsa terakhir ini pada hakekatnya berdampak pada gangguan pemenuhan kebutuhan dasar (pangan dan gizi) keluarga miskin (Sibariang,2010.).

Menurut World Health Organization (WHO) prevalensi anemia di dunia tahun 2015 sebanyak $24.8 \%$ dari total seluruh penduduk dunia yang hampir 2 milyar penduduk dunia. Indonesia sendiri prevalensi anemia yang didapatkan masih cukup tinggi, didapatkan angka kejadian anemia pada remaja mencapai presentasi 33,7 \%. Penelitian yang dilakukan Asian Development Bank yang dikutip Arumsari, 2008 menyebutkan sekitar 22 juta anak Indonesia terkena anemia. Menurut Tarwoto \& Wasnidar. 2013 anemia defisiensi zat besi yang tidak ditanggulangi akan berpengaruh pada kualitas generasi mendatang karena konsekuensi anemia di masa kanak-kanakakan berlanjut sampai dewasa.

Menurut Sandi 2014 Kejadian anemia di pengaruhi oleh beberapa faktor. Faktor status gizi mempengaruhi terjadinya anemia maka konsumsi makanan sebagai asupan gizi remaja putri perlu mendapatkan perhatian yang utama. Oleh karena itu di sarankan untuk masyarakat pedoman umum gizi seimbang atau PUGS melalui sekolah dan cara memilih makanan yang sehat dan pengetahuan kesehatan mengenai kesehatan reproduksi remaja perlu di berikan sedini mungkin. Faktor sosial ekonomi remaja dengan ekonomi rendah cenderung mengalami gizi kurang. Hal tersebut akan berpengaruh pada kemampuan untuk konsumsi makanan dan zat gizi sehingga keadaan tersebut memungkinkan untuk terjadinya anemia pada remaja. Dari penelitian yang pernah dilakukan oleh Dian Gunat maningsih yang berjudul faktor-faktor yang berhubungan dengan kejadian anemia pada remaja putri di SMA Negeri 1 Kecamatan Jatibarang Kabupaten Brebes tahun 2007. Diperoleh hasil uji statistic dengan chi-square antara variabel status gizi dengan kejadian anemia diperoleh $p=0,002(p<$ $0,05)$ yang artinya ada hubungan secara signifikan antara status gizi dengan kejadian anemia.

Dampak anemia pada remaja putri yaitu tubuh pada masa pertumbuhan mudah terinfeksi, mengakibatkan kebugaran atau kesegaran tubuh berkurang semangat belajar atau prestasi menurun, sehingga pada saat akan menjadi calon ibu dengan keadaan beresiko tinggi. Berdasarkan data diatas penulis tertarik untuk melakukan penelitian tentang hubungan antara status gizi dengan kejadian anemia pada remaja putri di SMAN 1 Pagelaran Pringsewu

\section{METODE}

Penelitian ini merupakan penelitian analitik dengan pendekatan cross sectional. Penelitian di lakukan di SMA N I Pagelaran Pringsewu pada remaja putri kelas XI. Populasi penelitian yang digunakan adalah semua remaja putri di SMAN 1 Pagelaran kelas XI yang berjumlah 96 responden. Teknik pengumpulan data dalam penelitian ini adalah pengisian lembar ceklist oleh peneliti dengan cara melakukan penimbangan berat badan dan mengambil sampel darah langsung pada responden. Analisis data yang digunakan dengan uji statistik Chi Square. 
Vol 10 No 1 Januari 2021 | Page 42-47

\section{HASIL}

\section{Analisis Univariat}

Distribusi frekuensi berdasarkan Status gizi

Tabel 4.1 Distribusi Frekuensi Status Gizi Pada Remaja Puteri di SMAN 1 Pagelaran Pringsewu

\begin{tabular}{lcc}
\hline \multicolumn{1}{c}{ Status gizi } & Jumlah & Persentase $(\%)$ \\
\hline Kurus $(<18,5)$ & 13 & 13,5 \\
Normal $(18,5-25,0)$ & 70 & 72,9 \\
Gemuk $(>25,0)$ & 13 & 13,5 \\
\hline \multicolumn{1}{c}{ Total } & 96 & 100
\end{tabular}

Berdasarkan tabel 4.1 dari 96 remaja didapatkan hampir seluruh responden mempunyai status gizi normal yaitu sebanyak 70 (72,9\%) dan sebagian kecil mempunyai status gizi kurus dan status gizi gemuk sebanyak $13(13,5 \%)$.

\section{a. Distribusi frekuensi kejadian anemia}

Setelah melakukan pengumpulan dan pengolahan data terhadap 96 responden, maka didapatkan distribusi frekuensi berdasarkan kejadian anemia sebagaimana dapat dilihat pada tabel berikut :

Tabel 4.2 Distribusi ferkuensi kejadian anemia pada remaja putri di SMAN 1 Pagelaran Pringsewu

\begin{tabular}{ccc}
\hline Kejadian anemia & Jumlah & Persentase (\%) \\
\hline Anemia & 20 & 20,8 \\
Tidak anemia & 76 & 79,2 \\
\hline Total & 96 & 100 \\
\hline
\end{tabular}

Berdasarkan tabel 4.2 diketahui bahwa lebih dari sebagian responden tidak mengalami anemia yaitu sebanyak 76 orang $(79,2 \%)$ dan sebagian responden mengalami anemia yaitu sebanyak 20 orang $(20,8 \%)$.

Analisis Bivariat

Tabel 4.3 Hubungan Status Gizi dengan Kejadian Anemia pada Remaja Putri di SMAN 1 Pagelaran Pringsewu

Kejadian anemia

\begin{tabular}{cccccccc}
\cline { 2 - 6 } Status gizi & Anemia & \multicolumn{3}{c}{ Tidak anemia } & Total & P-value \\
\cline { 2 - 6 } & $\mathrm{N}$ & $\%$ & $\mathrm{~N}$ & $\%$ & $\mathrm{~N}$ & $\%$ \\
\hline Kurus & 11 & $55 \%$ & 2 & $2,6 \%$ & 13 & $13,55 \%$ & \\
Normal & 5 & $25 \%$ & 65 & $85,6 \%$ & 70 & $72,9 \%$ & 0,000 \\
Gemuk & 4 & $20 \%$ & 9 & $11,8 \%$ & 13 & $13,55 \%$ & \\
\hline Total & 20 & $100 \%$ & 76 & $100 \%$ & 96 & $100 \%$ & \\
\hline
\end{tabular}


Berdasarkan hasil penelitian yang didapatkan diketahui bahwa dari 96 responden dengan status gizi kurus sebanyak 13 yaitu 11 (55\%) yang mengalami anemia dengan status gizi kurus, 2 $(2,5 \%)$ yang tidak mengalami kejadian anemia dengan status gizi kurus. Kemudian pada status gizi normal berjumlah sebanyak 70 yakni $5(25 \%)$ siswi yang mengalami anemia dengan status gizi normal dan sebanyak $65(85,6 \%)$ siswi yang dengan status gizi normal sedangkan tidak mengalami kejadian anemia remaja dengan status gizi gemuk berjumlah 13 remaja putri diantaranya 4 (20\%) mengalami anemia dengan status gizi gemuk dan $9(11,8 \%)$ siswi tidak anemia dengan status gizi gemuk. Hasil analisis bivariat didapatkan p-value 0,000 dapat disimpulkan ada hubungan status gizi dengan kejadian anemia pada remaja puteri di SMAN 1 Pagelaran Pringsewu.

\section{PEMBAHASAN}

\section{Status gizi}

Hasil univariat status gizi pada remaja sebagian besar normal yaitu 70 remaja $(72,9 \%)$ dari 96 responden. Menurut Adiani \& Wirjatmadi, 2012 status gizi baik atau normal di usia remaja sangat diperlukan terutama remaja putri agar di masa kehamilannya nanti sehat dan pertambahan berat badannya adekuat. Penelitian ini diperkuat dengan hasil penelitian Rumpiati, Ella \& Mustafidah (2010), remaja mempunyai keadaan gizi yang berbeda-beda yaitu berat badan dan tinggi badan serta riwayat gizi yang berbeda pula. Seorang yang memiliki status kesehatan yang baik, maka pertumbuhan dan perkembangan juga akan optimal. Dari hasil yang didapatkan peneliti, Terpenuhinya kebutuhan nutrisi secara adekuat melalui faktor yang mempengaruhi status gizi diantaranya status ekonomi, status kesehatan dan aktifitas responden secara merata menjadi penyebab sebagian besar status gizi bernilai normal, tetapi sebagian responden mengalami status ekonomi yang tidak mencukupi, remaja mempunyai keadaan gizi yang berbeda-beda yaitu berat badan, tinggi badan, riwayat penyakit serta riwayat gizi yang berbeda dan aktivitas yang menuntut para remaja SMAN 1 Pagelaran sehingga responden mengalami status gizi kurang dan lebih.

\section{Kejadian anemia pada remaja}

Berdasarkan hasil penelitian pada 96 siswi diketahui bahwa yang mengalami anemia sebanyak 20 siswi (20,8\%). Anemia defisiensi besi adalah anemia yang terjadi akibat kekurangan zat besi dalam darah (Proverawati, 2010). Berdasarkan uraian diatas dapat disimpulkan pada remaja yang mengalami kejadian anemia kemungkinan disebabkan oleh beberapa hal yaitu status gizi yang kurang baik seperti kurangnya informasi mengenai asupan gizi seimbang sehingga mempengaruhi pola konsumsi dan penyerapan (absorbsi) makanan kedalam tubuh berlangsung tidak normal dan kehilangan darah yang disebabkan menstruasi. Ada pula yang tidak mengalami anemia disebabkan karena status gizi dan penyerapan responden dalam keadaan baik serta responden sedang tidak mengalami menstruasi.

\section{Hubungan Status Gizi dengan Kejadian Anemia Pada Pemaja Puteri di SMAN 1 Pagelaran Pringsewu}

Hasil penelitian menggunakan uji Chi Square menghasilkan nilai p-value $<0,05$ yaitu p-value = 0,000 yang berarti ada hubungan antara status gizi dengan kejadian anemia pada remaja putri di SMAN 1 Pagelaran Pringsewu. Semakin baik status gizi seseorang maka semakin rendah seseorang tersebut kemungkinan untuk mengalami anemia. penelitian Rumpiati, dkk (2010) bahwa gizi atau nutrisi yang baik pada masa remaja memungkinkan kesehatan yang baik, pertumbuhan dan pekembangan yang optimal, gizi yang cukup dan baik juga membentuk kecerdasan otak, jiwa dan 
kehidupan sosial. Status gizi pada remaja dapat ditingkatkan dengan mengkonsumsi makanan yang memenuhi zat-zat gizi. Status gizi mempunyai korelasi positif dengan konsentrasi Hemoglobin, artinya semakin buruk status gizi seseorang maka semakin rendah kadar Hbnya. Penelitian yang dilakukan peneliti sejalan dengan penelitian yang dilakukan (Wibowo dkk, 2013) yang berjudul hubungan antara status gizi dengan anemia pada remaja Putri di SMA Muhammadiyah 3 Semarang dengan hasil uji statistik $\mathrm{p}=0,05$ Chi Square didapatkan nilai $\mathrm{p}$-value $=0,000$ maka dapat disimpulkan bahwa ada hubungan yang bermakna antara status gizi dengan anemia.

Berdasarkan uraian diatas, dari hasil penelitian bahwa 13 responden status gizi kurus, lebih banyak yang mengalami anemia dibandingkan dengan remaja yang tidak mengalami kejadian anemia, peneliti sempat bertanya pada responden yang mengalami anemia kemungkinan hal itu disebabkan oleh faktor sosial ekonomi yang kurang hal tersebut akan berpengaruh pada kemampuan untuk konsumsi makanan dan zat gizi sehingga keadaan tersebut memungkinkan untuk terjadinya anemia pada remaja. Kemudian responden yang memiliki status gizi normal dan tidak mengalami anemia hal ini disebabkan karena makanan yang dikonsumsi oleh responden sudah mengandung semua zat gizi yang diperlukan oleh tubuh responden, sehingga terjadi keseimbangan antara zat gizi yang dikonsumsi oleh responden dengan zat gizi yang diperlukan oleh tubuh.

\section{SIMPULAN}

Mayoritas status gizi pada remaja puteri di SMAN 1 Pagelaran mayoritas normal sebanyak 70 siswi $(72,9 \%) \%)$ dan keajdian anemia pada remaja puteri sebanyak 76 orang $(79,2)$, dan terdapat hubungan cukup kuat. Sehingga dapat disimpulkan terdapat hubungan cukup kuat antara status gizi dengan kejadian anemia pada remaja puteri kelas XI di SMAN 1 Pagelaran Pringsewu Lampung. Dengan analisis Chi square diperoleh nilai $p$-value $(0,000)<\alpha(0,05)$

\section{SARAN}

Peneliti menyarankan pada pihak sekolah untuk lebih meningkatkan sosialisasi cara memilih makanan yang sehat dan memberikan sosialisasi atau bimbingan kepada siswa-siswi pada saat memberikan pembelajaran supaya dapat menjaga kecukupan gizi untuk meningkatkan prestasi belajarnya.

\section{DAFTAR PUSTAKA}

Proverawati, A. (2011). Anemia dan anemia kehamilan. Yogyakarta: Nuha Medika.

Sandi J. W. Madden. A. HoldSword, M. (2014). Gizi dan Diet Etika. EGC Jakarta.

Sibariang, S. S. (2010). Gizi dan Kesehatan Reproduksi. Jakart. Trans Informasi

Rumpiati, Ella, F \& Mustafidah, H. (2010). Hubungan antara status gizi dengan kejadian anemia pada remaja putri. [Internet]. Di peroleh pada taggal 9 februari 2015 di http://jurnalmediagizipangan.files.wordpress.com/2015/09/hubungan-tingkat-pengetahuan-danstatus-gizi-terhadap-kejadian-anemia-remaja-putri.pdf.

Notoatmodjo, S. (2010). Metodologi penelitian kesehatan. Jakarta: Rineka Cipta. 
Vol 10 No 1 Januari 2021 | Page 42-47

Adriani, M., \& Wirjatmadi, B. (2012). Peran gizi dalam status kehidupan. Jakarta: Kencana Prenada Media Group.

Muhammad \& Asrori, M.( 2014). Psikologi Remaja Perkembangan Peserta Didik. PT Bumi Aksara. Jakarta

Notoatmodjo, S.( 2012). Metodologi penelitian kesehatan. Jakarta: Rineka Cipta.

Nursalam, (2003). Konsep Dan Penerapan Metode Penelitian Ilmu Keperawatan, Jakarta : Salemba Utama

Arikunto, S. (2010). Prosedur Penelitian, Jakarta : Rineka Cipta.

Almatsier, S (2011). Prinsip Dasar Ilmu Gizi. Jakarta : Gramedia Pustaka Utama.

Septiasari, Y dkk (2020). Screening Anemia pada Ibu Hamil di Puskesmas Bernung Kabupaten Pesawaran Lampung. JURNAL CEMERLANG: Pengabdian pada Masyarakat. Vol 3 no 1. DOI: https://doi.org/10.31540/jpm.v3i1.1028

Soekatri, M. (2011). Penelitian Status Gizi (Gizi Dalam Daur Kehidupan), PT Gramedia Pustaka Utama.

Sugiyono, (2012). Metode Penelitian Deskripsi \& Kualitatif. Dan R \& D, Alfabet. Bandung

Sulistianingsih, A dan Saputri, N. (2020). Kehamilan Bebas Anemia:Pendekatan menggunakan information motivation (IMB) Skill Model. Rumahkayu Pustaka: Padang

Tarwoto \& Wasnidar. (2013). Anemia Pada Ibu Hamil, Konsep dan Penatalaksanaan. Trans Informedia

Proverawati, A. (2010). Obesitas dan Gangguan Perilaku Makan pada Remaja. Yogyakarta. Penerbit Muha Medika.

Wibowo dkk. (2013). Hubungan antara status gizi dengan anemia pada remaja Putri di SMA Muhammadiyah 3 Semarang. Skripsi UMS 